\title{
Adrian TYSZKIEWICZ
}

Uniwersytet Jagielloński

a_dran@poczta.fm

\section{W OKOWACH „DEMOKRATYCZNEGO \\ CENTRALIZMU” - PRZYPADEK \\ STRONNICTWA DEMOKRATYCZNEGO W PRL}

ABSTRACT In the grip of "democratic centralism" - the case of The Democratic Party in The People Republic of Poland

So - called "democratic centralism", originally created by W. Lenin, was the main principle used by the communist party (PPR/PZPR) in Poland after the World War II to control the society and its organizations. One of them was a Democratic Party established in the 1939 by the politicians and activists rooted in the left - oriented independence movement, of whom Marshall Józef Piłsudski said to has been the icon and the undisputed leader. After the war the Democratic Party was enslaved by the communists and became the part of the rule system. It was said to be the representative of the systematically vanishing middle class (craftsmen, merchants, intelligence), due to the thesis of Stalin concerning the raging class struggle. Until the fall of the totalitarian system in 1989 the Democratic Party officially supported the communists who overwhelmed every aspect of political reality. That is why the phenomenon of political realism was not involved in its policy despite of being the part of the official propaganda. Nevertheless, in the party structures dwelled the resistance that headed for the independence, of whom Karol Głogowski or Przemysław Górny were the leaders. The Democratic Party conversed in 1989 and supported the first democratic government of Tadeusz Mazowiecki.

Keywords: communism, political movements, The Democratic Party, support party, political realism

Słowa kluczowe: komunizm, ruchy polityczne, Stronnictwo Demokratyczne, ugrupowanie satelickie, realizm polityczny 


\section{SD JAKO ELEMENT SCENY POLITYCZNEJ POLSKI PRZEDWRZEŚNIOWEJ}

Stronnictwo Demokratyczne powstało w wyniku kreacji i działalności od jesieni 1937 r. Klubów Demokratycznych, które sprzeciwiały się autorytarnemu modelowi państwa i społeczeństwa propagowanemu przez będący u władzy Obóz Zjednoczenia Narodowego. Twórcy ugrupowania rekrutowali się z demokratycznych środowisk byłych legionistów, peowiaków, lewicy sanacyjnej związanej m.in. ze Związkiem Naprawy RP, a także z lewicującej części Związku Pracy dla Państwa „Legion Młodych” oraz radykalnych społecznie inteligentów i grup młodzieży ${ }^{1}$.

Stronnictwo oficjalnie powołane zostało w kwietniu 1939 r. na Ogólnopolskim Zjeździe Założycielskim (I Kongres) w Warszawie. Linię polityczną nowego ugrupowania wyznaczały metryki polityczne czołowych działaczy ${ }^{2}$ oraz niezgoda na ograniczającą swobody obywatelskie ewolucję systemu „rewolucji majowej”. Stąd konkretne postulaty nie zmierzały zrazu do obalenia, lecz do istotnej reformy systemu w kierunku restytucji wartości demokratycznych. Do klasycznych należały postulaty: reformy ordynacji wyborczej do Sejmu i Senatu oraz szeroki program przeobrażeń społeczno-gospodarczych, który charakteryzował się powrotem do wzorów demokratycznych ukształtowanych na podstawie rzeczywistego stosowania zapisów Konstytucji Marcowej (m.in. w pełni demokratyczne prawo wyborcze, poszanowanie prawa i wolności obywatelskich, radykalna obrona praworządności i niezawisłości sądów, krytyka tendencji nacjonalistycznych oraz totalitarnych mogących wpływać na destabilizację państwa). Personifikacją wartości i programu politycznego Stronnictwa stał się zatem obywatel cieszący się wolnością i zdobyczami systemu demokratycznego, hołdujący podstawowej wartości wspólnotowej, za jaką uznano pracę, kreatorkę mocarstwowości państwowej.

Wspomniany wyżej zbiór wartości demokratycznych istotnie wpływał na wizję systemu rządów. Raz jeszcze, jak u początków odrodzonej państwowości, z Sejmu chciano uczynić centrum decyzji politycznej, które kontrolowałoby prace rady ministrów. Postulat współudziału obywateli w rządzeniu państwem zamierzano realizować za sprawą szerokiego, niezależnego samorządu terytorialnego, zawodowego i gospodarczego. Kontrolę nad funkcjonowaniem nawy państwowej zapewnić miała silna pozycja Trybunału Konstytucyjnego.

Program społeczny demokratów zakładał wolność prasy i zrzeszania się, powszechny dostęp do kultury, walkę z analfabetyzmem, zacofaniem - tutaj jako rozwiązanie jawiła się bezpłatna na każdym stopniu oświata oraz system burs i stypendiów oraz równo-

O środowiskach politycznych, z których wywodzili się działacze Stronnictwa Demokratycznego, zob. A. Czubiński, Stronnictwo Demokratyczne (1937-1989). Zarys dziejów, Poznań 1998, s. 25-36, Publikacje Instytutu Historii UAM, 24.

2 Wśród grupy przywódczej SD wiele osób związanych było z przedwojennym ruchem piłsudczykowskim, m.in.: Mieczysław Michałowicz (PPS), Regina Fleszarowa (Związek Strzelecki) czy Mikołaj Kwaśniewski i Stanisław Więckowski (Legiony). 
uprawnienie wyznań. SD zakładało realną współpracę z mniejszościami narodowymi uznanie ich praw politycznych oraz uprawnienia do rozwoju gospodarczego, kulturalnego i politycznego, w czym widziano drogę do harmonijnego zespolenia z państwem i większością polską. Była to zatem kolejna wersja piłsudczykowskiej konsolidacji państwowej, jednakże z podkreśleniem zasad dobrowolności i podmiotowości.

Wizja systemu gospodarczego oparta była na planowości, w czym upatrywano drogę do: pełnego zatrudnienia, udziału w redystrybucji dóbr oraz stworzenia realnego efektu wzrostu stopy życiowej. Przewidywano trzy sektory gospodarowania, tj. państwowy, spółdzielczy i prywatny, przy czym podstawowe gałęzie powinny pozostawać w rękach państwa i samorządów. Tym ostatnim przypisywano kluczową rolę, gdyż miały być widomą oznaką działania demokracji - w ramach samorządu funkcjonowałyby zakłady rzemieślnicze oraz wytwórcze. Inicjatywie prywatnej należeć się miała realna opieka i pomoc ze strony państwa. Powszechnie funkcjonować miał także akcjonariat pracowniczy, system szerokiej opieki społecznej oraz ruch związkowy.

Stosunki z zagranicą zrywały z sanacyjnym aksjomatem dwóch geopolitycznych potęg. Odrzucając beckowską praktykę polityczną, postulowano rewitalizację i zacieśnienie stosunków z Francją, zbliżenie z Wielką Brytanią, USA oraz Czechosłowacją i Litwą. Działania takowe posłużyć powinny uzyskaniu pozycji naczelnej w ówczesnej Europie Środkowej ${ }^{3}$.

Paradoksem tak zarysowanej wizji systemu politycznego było funkcjonowanie wśród elit SD silnego syndromu autorytarnego, stanowiącego efekt nawiązania do dziedzictwa Marszałka Piłsudskiego. Tym samym środowisko SD można uznać za progresywnych piłsudczykowskich epigonów, czego znakomitym wyrazem była akceptacja dla republiki prezydenckiej, gdzie głowa państwa to najważniejszy jego element, harmonizujący tzw. przerosty parlamentaryzmu i biurokracji. Nie sposób nie zauważyć w takiej konstrukcji wewnętrznych sprzeczności. Biorąc jednak pod uwagę ówczesny charakter polskiej sceny politycznej oraz miarę rzeczywistego wpływu opozycji na działania obozu pomajowego, należy widzieć w takowej niekonsekwencji próbę godzenia z realiami systemu politycznego elementów własnej, związanej z politycznymi korzeniami tradycji o demokratycznym zabarwieniu.

\section{CZAS WOJNY}

Po wybuchu II wojny światowej Stronnictwo Demokratyczne podlegało podobnie jak inne ugrupowania polityczne procesowi czasowej dezintegracji. Po reaktywacji jesienią 1940 r. i przyjęciu konspiracyjnego kryptonimu „Prostokąt” udzieliło Stronnictwo jednoznacznego poparcia legalnemu rządowi RP na uchodźstwie. Ogłoszona we wrześniu

Deklaracja Klubu Demokratycznego z 16 października 1937 r.; Deklaracja programowa Stronnictwa Demokratycznego [1939], [w:] Materiaty do historii Klubów Demokratycznych i Stronnictwa Demokratycznego w latach 1937-1939, cz. 1, wstęp i oprac. L. Chajn, Warszawa 1964, s. 162-166, 515-522; W. Żebrowski, Stronnictwo Demokratyczne w warunkach demokratyzacji ustroju politycznego, Olsztyn 2003, s. 17-25. 
tego roku Deklaracja ideowa klarownie określała Polskę jako państwo rozdarte pomiędzy dwóch agresorów; stąd totalitarna ideologia sowiecka uznana została za równoważną z nazizmem i scharakteryzowana jako zbrodnicza i obca mentalności polskiej.

Gros członków SD znalazło miejsce w strukturach Polskiego Państwa Podziemnego, takich jak ZWZ czy później AK, piastując tam również odpowiedzialne stanowiska. Do takowych należał major Jerzy Makowiecki, który kierował Wydziałem Informacyjnym Biura Informacji i Propagandy KG AK, zastąpiony później przez Aleksandra Gieysztora i Kazimierza Moczarskiego. W BIP czynni byli także Marceli Handelsman oraz Ludwik Widerszal, obaj odpowiedzialni za sprawy międzynarodowe. Działacze SD organizowali i uczestniczyli jednocześnie w pracach Referatu Pomocy Żydom „Żegota” oraz Społecznej Organizacji Samoobrony - tutaj wyróżniali się wspomniany uprzednio Moczarski oraz Marek Ferdynand Arczyński.

Pomimo wyrazistego stanowiska niepodległościowego ugrupowanie zostało zepchnięte na margines podziemnej polityki - próżno szukać „Prostokąta” w Politycznym Komitecie Porozumiewawczym czy Krajowej Reprezentacji Politycznej. Sytuacja takowa była pokłosiem stanowiska Stronnictwa Narodowego, które, oskarżając demokratów o sympatie prokomunistyczne oraz udział w masońskich sprzysiężeniach, odmawiało SD prawa do godnego reprezentowania interesów państwa i narodu.

Program polityczny ogłoszony w czasie okupacji miał jednoznaczne znamiona syntezy doświadczeń przedwojennych oraz uwzględnienia zmienionych wybuchem wojny warunków geopolitycznych. W kwietniu 1943 r. SD ogłaszało zatem wizję tzw. demokracji integralnej mającej być połączeniem pluralistycznej formuły państwa oraz demokratycznych stosunków społeczno-gospodarczych. Postulaty takie jak równość ekonomiczna czy sprawiedliwość społeczna winny stać się siłami sprawczymi proponowanej formy i treści ustrojowo-społecznej. Rzeczpospolita Polska postrzegana była jako byt egzystujący pomiędzy zachodnimi neodemokracjami i totalizmami, stąd konieczność kreacji nowego ładu stawała się treścią wychodzącą naprzeciw imperatywowi obrony suwerenności. Tak więc za sprawą ideologii społecznego egalitaryzmu, dobrobytu i poszanowania podstawowych praw jednostki realizowanych w republice demokratycznej, opartej na pięcioprzymiotnikowej ordynacji wyborczej, niezawisłości organów sądowych oraz systemie prezydenckim (głowa państwa charakteryzująca się nadrzędną rolą jawiła się jako spoiwo systemowe), proponowano realizację swoistej trzeciej drogi jako opcji rozwojowej na czas pokojus.

SD nie dotrwało jednakże in corpore do zakończenia działań wojennych. Różnica zdań co do oceny działań Związku Sowieckiego oraz powojennych sojuszy doprowadziła do rozłamu. Większość działaczy Stronnictwa, z Jerzym Makowieckim, opowiadając się jednoznacznie przeciw PPR, a postulując m.in.: granicę na Odrze, równouprawnienie mniejszości narodowych, federację w Europie Środkowej, system parlamentarny, uspołecznienie przemysłu, parcelację wielkich majątków oraz opartą na szerokiej

Deklaracja Ideowa podziemnego Stronnictwa Demokratycznego z września 1940 r., „Zeszyty Historyczno-Polityczne Stronnictwa Demokratycznego" 1988, nr 1, s. 114-117.

5 Projekt „Deklaracji Ideowej” opracowany w krakowskim ośrodku podziemnego SD (fragment), „Zeszyty Historyczno-Polityczne Stronnictwa Demokratycznego" 1990, z. 4, s. 90. 
spółdzielczości gospodarkę planową - znalazła miejsce w Radzie Jedności Narodu. Od lipca 1944 r. wraz z Polską Niepodległą oraz Związkiem Wolnej Polski Stronnictwo zainicjowało prace Zjednoczenia Demokratycznego, na czele którego staną Eugeniusz Czarnowski, aresztowany niespełna rok później wraz z innymi przywódcami PPP przez NKWD (po aresztowaniu zastąpił go Zygmunt Kapitaniak).

Zjednoczenie wykazało się bezwzględną krytyką KRN i komunistów. Opowiadało się za pełną suwerennością i integralnością terytorialną, proponując także realizację aliansu z Litwą jako remedium na realne niebezpieczeństwo uczynienia z RP przez komunistów kolejnej republiki sowieckiej. W tym duchu w marcu 1945 r. sformułowana została uchwała, w którejZD wzywało m.in. do likwidacji Rządu Tymczasowego i utworzenia całkowicie od komunistów niezależnego centrum politycznego, które przeprowadzi w pełni wolne wybory. Głoszony program kwitowała koncepcja powołania Obozu Demokracji Polskiej, skierowanego przeciw totalistycznym siłom lewicy komunistycznej oraz bliżej nieokreślonym elementom konserwatywno-zachowawczym i faszystowskim ${ }^{6}$.

We wrześniu 1945 r., ze względu na akcje komunistycznego aparatu bezpieczeństwa i przejście do legalnej walki politycznej, zgodnie z testamentem Polski Podziemnej Zjednoczenie uległo rozwiązaniu. Wielu członków ZD, próbując odnaleźć się w nowych warunkach i prowadzić działalność zgodnie z interesem polskiej racji stanu, zgłosiło akces do rewitalizowanego po okresie wojny Stronnictwa Demokratycznego, w którym, jak się wkrótce miało okazać, nie przewidziano miejsca dla swobodnego dyskursu politycznego.

Ugrupowaniem rozłamowym o lewicowym, choć dalekim od sprzyjania proweniencji komunistycznej, nachyleniu było Stronnictwo Polskiej Demokracji na czele z Romualdem Millerem. W listopadzie 1943 r. ukonstytuował się także sprzyjający opcji lewicowej autonomiczny Ruch Młodej Demokracji z Leszkiem Guzickim, z tym że organizacja ta od zarania działalności skłaniała się ku komunistom. Wyrazem tejże tendencji stało się klarowne opowiedzenie się za bezwzględną walką z hitleryzmem prowadzoną przez siły radykalnie demokratyczne oraz brak takiego stosunku wobec totalizmu sowieckiego.

W lutym 1944 r. SPD z innymi organizacjami lewicowymi (m.in. syndykaliści i Bund) utworzyło tzw. Centralizację Stronnictw Demokratycznych, Socjalistycznych i Syndykalistycznych, która w założeniach wyrażała ambicje stania się obok ugrupowań niepodległościowych i KRN trzecią liczącą się siłą polityczną. Po rozwiązaniu działacze Centralizacji zasilali kadry odradzającego się „lubelskiego” SD.

\section{W NOWEJ POLSCE}

Restytucja jednolitego SD dokonała się w Lublinie w lipcu 1944 r., kiedy to Wincenty Rzymowski, członek Związku Patriotów Polskich, w imieniu Stronnictwa podpisał ma-

Uchwata Zjednoczenia Demokratycznego [1945], „Zeszyty Historyczno-Polityczne Stronnictwa Demokratycznego" 1990, nr 3, s. 100-102. 
nifest PKWN. Tym samym SD wraz z PPR, PPS i SL „Wola Ludu” oficjalnie utworzył ośrodek władzy alternatywny wobec legalnej krajowej reprezentacji stronnictw skupionych w RJN oraz wobec rządu w Londynie.

W „lubelskim” SD kierownictwo przechwycone zostało przez ideowych komunistów 7 . Do grupy tej należeli byli działacze KPP i organizacji tworzonych w Związku Sowieckim, tj. m.in.: Leon Chajn, Wacław Barcikowski, Jan Rabanowski, Jan Karol Wende, Zbigniew Sobolewski, Leon Chwistek, Eugenia Krassowska czy wspomniany już Wincenty Rzymowski. Nowa grupa kierownicza zadanie miała w wielkiej mierze ułatwione, gdyż opowiadając się za kształtującą się, nową legalnością, uzyskała materialną legitymację od wkraczających na tereny tzw. Polski lubelskiej jednostek frontowych Armii Czerwonej oraz NKWD.

Stronnictwo oficjalnie wznowiło działalność za sprawą wyboru w dniu 18 sierpnia 1944 r. Tymczasowego Zarządu Głównego z Rzymowskim na czele, a zatem podpis tego ostatniego w imieniu SD pod lipcowym aktem PKWN należy uznać za jednoznaczną mistyfikację, gdyż organizacja formalnie jeszcze wówczas nie istniała. Niemniej jednak w rzeczywistości stanu wyjątkowego element siłowy, odgrywający rolę konstytutywną, stał po stronie grupy lubelskiej. Reminiscencje tych faktów okazały się brzemienne w skutki, szczególnie dla działających cały czas Zjednoczenia Demokratycznego oraz Stronnictwa Polskiej Demokracji, gdyż niespodziewanie musiały one zmierzyć się z trzecim, pretendującym do roli współdzierżyciela rodzącej się władzy konkurentem, odwołującym się przy tym do tzw. postępowych haseł przedwojennego Stronnictwa. Naturalną zatem w ówczesnych warunkach dla nich konsekwencją była decyzja o zaprzestaniu działalności, w wyniku której szereg aktywistów zgłosiło akces do „lubelskiego" SD.

"Odrodzone" Stronnictwo potwierdziło otwarcie nowego rozdziału w swojej historii Deklaracją opublikowaną 28 września 1944 r., w której m.in. uznało KRN za jedynego reprezentanta narodu polskiego, a wojsko polskie pod dowództwem gen. Michała Roli-Żymierskiego w braterstwie z Armią Czerwoną, partyzantką antyfaszystowską i nowymi jednostkami - za wskrzeszające przyjaźń i jedność narodów słowiańskich za sprawą wspólnej tradycji oporu przeciw teutońskiemu nawałowi. Tę ostatnią tezę uzasadniać miało posłużenie się w dokumencie wątkiem grunwaldzkim ${ }^{8}$.

$\mathrm{Na}$ wiosnę 1945 r. kierownictwo SD przeniosło się do Warszawy. Fakt ten, związany z bytnością ugrupowania w oficjalnej, acz faktycznie grającej rolę dekoracyjno-propagandową, Centralnej Komisji PorozumiewawczejStronnictw Demokratycznych, oraz powolny rozpad struktur PPP wpłynęły na rozrost organizacyjny, gdyż wielu członków przedwojennego SD oraz działaczy ZD i SPD zasilało szeregi Stronnictwa.

Zastosowano tu tzw. metodę wtyczek, sięgającą rodowodem czasów II Rzeczpospolitej, polegającą na oddelegowywaniu funkcjonariuszy partyjnych do innych ugrupowań politycznych w celu ich infiltracji. Zob. J. Wrona, SD w systemie politycznym PRL 1944-1965. Studium krytyczne, „Zeszyty Historyczno-Polityczne Stronnictwa Demokratycznego" 1990, nr 3, s. 71-72. Podobne metody w latach 30. stosował także nielegalny Ruch Narodowo-Radyklany „Falanga” Bolesława Piaseckiego.

8 Deklaracja Stronnictwa Demokratycznego, [w:] Stronnictwo Demokratyczne w Polsce Ludowej, cz. 1: Wybór dokumentów z lat 1944-1949, Warszawa 1968, s. 15-23. 
Dla charakteru oraz pozycji politycznej SD ówcześnie, a i w latach późniejszych, kluczową okazała się rola, która była udziałem Leona Chajna, wieloletniego sekretarza generalnego partii. Pomimo wielu przypadków terenowej współpracy z Mikołajczykowskim PSL, Stronnictwem Pracy Karola Popiela, a nawet nieufną PPS, Stronnictwo Demokratyczne wkroczyło na drogę odgórnej uniformizacji i totalizacji. Chajn bowiem był odpowiedzialny za wprowadzanie partyjnej dyktatury - w tym celu doprowadził do scentralizowania aparatu oraz do działań represyjnych wobec niepokornych działaczy. Znakomite exemplum stanowił przypadek Dobromira Osińskiego, przedstawiciela Stronnictwa w KRN. Chajn przyczynił się w 1946 r. do odebrania mu mandatu, gdyż na posiedzeniu Komisji Morskiej i Handlu Zagranicznego Osiński solidaryzował się z działaczami PSL9 .

Pomimo zaznaczającej się przewagi grupy kryptokomunistów, w SD działała także opcja liberalno-demokratyczna, reprezentowana m.in. przez działaczy krakowskich: prof. Adama Krzyżanowskiego czy Jerzego Langroda. Krytykowali oni podle wzorów sowieckich przeprowadzaną industrializację, wyrażali przyjazny stosunek do PSL, atakowali nową, pseudodemokratyczną ordynację wyborczą. Podobną postawę przyjęła organizacja katowicka SD, werbalizując m.in. stanowisko odnośnie do autonomicznej listy wyborczej przed elekcją do Sejmu Ustawodawczego w 1947 r. oraz oficjalnie broniąc honoru żołnierzy Armii Krajowej, z których wielu włączano do prac Stronnictwa na Śląsku.

W styczniu 1946 r. SD ogłosiło tzw. Tezy Programowe. Wyrażano w nich jednoznacznie wolę oparcia autoidentyfikacji politycznej na manifeście PKWN, ale za sprawą bezpośredniego odniesienia do tradycji reformatorskiej Sejmu Wielkiego, insurekcji kościuszkowskiej czy działań Towarzystwa Demokratycznego Polskiego wskazywano na szersze niż klasowe podstawy działalności. Zapisy dokumentu postulowały ustrój zapewniający demokrację w polityce, sprawach społeczno-gospodarczych i kulturze. Twórcy „Tez” na tym jednak poprzestali. Alogicznie, acz zgodnie z dominującym oficjalnie trendem, uznali Konstytucję Marcową jako punkt wyjścia dla nowej formacji ustrojowej. Oprzeć się ona miała na Sejmie jako głównym ośrodku decyzji politycznej, uzupełnianym w terenie przez Rady Narodowe mające stanowić wyraz tzw. demokratycznej samorządności. System partyjny cechować powinny takie wartości jak pluralizm, egalitaryzm oraz wzajemne uznanie sił. W sposób oczywisty kłóciło się to z ówczesną ewolucją stosunków politycznych, zmierzającą do podziału na ugrupowania demokratyczne i faszystowską reakcję. Nowy ustrój gwarantować miał rządy prawa i wolności obywatelskie, np. wolność sumienia i wyznania, skutkując osiągnięciem stabilnej praworządności. Ukłonem programowym wobec własnej, przedwojennej tradycji było ujęcie pracy jako podstawy bogactwa, co w niewymuszony sposób zbiegało się z jednym z wniosków płynących z faktu uczynienia przez nową władzę mas pracujących formalnym suwerenem. Podstawę polityki zagranicznej upatrywano we współpracy i przyjaźni ze Związkiem Sowieckim, ale bazując na wartościach de-

J. Wrona, System partyjny $w$ Polsce 1944-1950. Miejsce, funkcje, relacje partii politycznych $w$ warunkach budowy i utrwalania systemu totalitarnego, Lublin 1997, s. 263. 
mokratycznych oraz istniejącej współpracy, postulowano pogłębianie relacji z USA, Wielką Brytanią i Francją ${ }^{10}$.

Wspomniane stanowisko zostało zaakceptowane jako podstawa programowa II Kongresu SD, który odbywał się latem 1947 r., a więc już po formalnym przechwyceniu władzy przez polskich komunistów i ugruntowaniu przez nich wpływu na działania zasadniczych elementów władczych, tj. instytucji Sejmu, Prezydenta i Rady Ministrów. Wewnątrz Stronnictwa skutkowało to wewnętrznymi rozliczeniami i pacyfikacją nastrojów, czego przejawem stało się m.in. odsunięcie demoliberalnych działaczy, takich jak Mieczysław Michałowicz czy Jerzy Langrod.

Antydemokratyczna ewolucja SD skutkowała ograniczeniem bazy społecznej, złożonej tradycyjnie ze środowisk inteligenckich oraz przybierającej liczebnie grupy rzemieślników, którzy starali się znaleźć w Stronnictwie wyraziciela swoich interesów zagrożonych w coraz większym stopniu przez narastającą opresyjność systemu politycznego. Liczebność struktur zmniejszała się sukcesywnie: ze 140 tys. członków w roku 1945 w cztery lata później pozostało jedynie 48 tys., co ze względu na warunki działania, czyli faktyczną omnipotencję partii komunistycznej oraz intensywną totalizację życia społeczno-politycznego, uznać można za wynik i tak względnie zadowalający. Niestety, z ugrupowania odchodzili wartościowi, pragnący reform społecznych działacze, którzy klarownie artykułowali niezależność polityczną, demokratyczną podmiotowość oraz utrzymanie zdrowych podstaw gospodarowania.

W październiku 1948 r. odbyło się brzemienne w skutki posiedzenie Rady Naczelnej SD, zwane w partyjnej nomenklaturze „Małym Kongresem”. Podczas obrad doszło do ukształtowania nowego politycznego credo, wynikającego ze szczególnych warunków działania i pracy - to nowe „wyznanie wiary” moderowane było bowiem w sposób zasadniczy przez warunki wyznaczone obiektywnością nowego, stalinowskiego ustroju. Paradoksalnie okazać się miało, iż uchwalone wtedy przez członków ówczesnej Rady zasadnicze wyznaczniki ideowo-programowe pozostały aktualne aż do XIV Kongresu SD z kwietnia 1989 r., odbywającego się już w warunkach początku transformacji ustrojowej.

Osią politycznego samookreślenia stała się następująca, fundamentalna konstatacja: Stronnictwo Demokratyczne, dopatrując się wperspektywie Polski Socjalistycznej podwalin jej petnej suwerenności państwowej oraz warunków jej ekonomicznego, socjalnego i kulturalnego postępu, będzie towarzyszyć masom pracujacym $w$ tym marszu ku socjalizmowi $i^{11}$. Oznaczało to faktyczne wyrzeczenie się zasadniczego dla istnienia demokratycznego ugrupowania pluralizmu poglądów, zastąpionego jedną, oficjalną ideologią. Do partyjnego dekalogu wprowadzono także tezy marksowskiej dialektyki, podnosząc pogląd o ostatecznym końcu kapitalizmu i początku ery socjalizmu.

10 Tezy programowe SD uchwalone przez I Zjazd Rady Naczelnej Stronnictwa Demokratycznego odbyty wdniach 20-23.01.1946 r. w Warszawie, [w:] Stronnictwo Demokratyczne w Polsce..., s. 50-60.

11 Rezolucja Rady Naczelnej SD uchwalona na posiedzeniu $w$ dniu 11.10.1948 r. w Warszawie, [w:] Stronnictwo Demokratyczne w Polsce..., s. 273. 
Ciekawym stało się nawiązanie do tzw. prawdziwego patriotyzmu, wiążacego suwerenność narodowa z walka o petna sprawiedliwość spoteczną ${ }^{12}$. Zapatrywanie takie zbieżne było z główną linią frakcji stalinowskiej w PPR, z Bolesławem Bierutem i Hilarym Mincem na czele, która znalazła m.in. wyraz w słynnym referacie tow. Tomasza pt. Walka narodu polskiego o pokój i Plan 6-letni oraz w esencji stanowisk z gruntu przeciwnych poglądom określanym jako „odchylenie prawicowo-nacjonalistyczne”, sformułowanym zwięźle w stanowisku Władysława Gomułki wyartykułowanym w czerwcu 1948 r. na posiedzeniu KC PPR.

SD popierało zatem podstawową koncepcję KPP uznającą rewolucję październikową za pierwotne źródło niepodległości Polski. Według tejże bowiem istota niepodległości to wyzwolenie społeczne i budowa nowego, sprawiedliwego i egalitarnego ładu, co prowadziło do konkluzji o istnieniu dwóch sił społecznych: prawdziwej i narodowej, bo popierającej socjalizm, oraz tej wstecznej, neofaszystowskiej i nacjonalistycznej, zwalczającej socjalizm. Takowa dychotomia nie pozostawiała więc żadnego wyboru prawdziwemu, wywodzącemu się z narodu utożsamianego z ludem patriocie, który intuicyjnie wręcz popierał rozwijającą się „,demokrację ludową"13.

Inne wnioski „Małego Kongresu” prowadziły do nakreślenia elementów z pozoru drugorzędnych, jednakże faktycznie definiujących Stronnictwo i jego długoletnią aktywność w ramach „ludowego” państwa: w budowie socjalizmu SD stawiało siebie w roli rzecznika gospodarki prywatnej, drobnotowarowej, służebnej wobec sektora uspołecznionego - chodziło tutaj o rzemiosło. Bazą społeczną stały się tzw. „warstwy pośrednie” (w domyśle: przejściowe, na wyboistej drodze przekształcania „ludowej demokracji” w socjalizm), jak mówiono ówcześnie o sferach mieszczańskich oraz inteligencji.

Ostateczną konkluzją programu, zaakceptowanego finalnie przez obradujący na przełomie września i października 1949 r. III Kongres SD, stało się charakterystyczne, rytualne uznanie istniejącego porządku geopolitycznego jako gwaranta postępu i słuszności obranej drogi: Ufni w trwatość naszych sojuszów z krajami demokratycznymi na czele ze Zwiąkiem Radzieckim, niezachwianym i wypróbowanym obrońca pokoju, ufni w potegę światowego obozu wolności i w solidarność wszystkich sit postępowych - jesteśmy pewni, że przysztość do nas należy $y^{14}$.

Od tego czasu, czyli od przełomu 1948 i 1949 r., SD jako ugrupowanie utraciło faktyczną, jednostkową sterowność, akceptując zasady leninowskiej koncepcji życia partyjnego, to jest tzw. centralizm demokratyczny. Jedna z publikacji ideologicznych z lat 70 . ujmowała istotę wzmiankowanego centralizmu jako jednolite, sprężyste kierowanie realizacją celów socjalizmu. Jednolite kierownictwo wymaga silnej pozycji wtadz centralnych partii $w$ stosunku do catej partii ${ }^{15}$. W kontekście organizacji społeczno-politycznych,

12 Tamże, s. 274.

13 Por. K. Tyszka, Nacjonalizm w komunizmie. Ideologia narodowa w Zwiazku Radzieckim i Polsce Ludowej, Warszawa 2004, s. 128-141.

14 Rezolucja Rady Naczelnej SD..., s. 279.

15 Organizacja polityczna spoteczeństwa socjalistycznego w Polsce, red. A. Dobieszewski, Warszawa 1977, s. 140 . 
szczególnie „bratnich stronnictw”, oznaczało to: po pierwsze, uznanie przez wszystkie legalnie działające organizacje naczelnej zasady budownictwa socjalistycznego, tj. kierowniczej roli partii marksistowsko-leninowskiej, po drugie, dozwolenie na samodzielność nierobotniczych stronnictw - takową ograniczano programem budownictwa socjalistycznego; miała ona wyrażać się w suwerenności wewnętrznej oraz możności prezentowania poglądów co do form, metod, tempa rozwiązywania problemów społeczno-politycznych, zarówno w procesie formułowania, jak i realizacji programu.

System realizował zasadę ścisłej hierarchii, charakterystycznej dla niedemokratyzmów różnej proweniencji. Rozróżniano zatem:

a) PZPR jako partię marksowsko-leninowską, w której z tego powodu obowiązywała ścisła dyscyplina vs. SD i ZSL jako organizacje prezentujące wiele światopoglądów, ale akceptujące budownictwo socjalistyczne;

b) PZPR jako partię klasy robotniczej vs. ZSL (partia chłopska) i SD, reprezentujące niemarksistowskie środowiska pracowników umysłowych oraz rzemiosło i drobny handel;

c) PZPR jako partię-, przewodniczkę"16 budownictwa socjalistycznego vs. ZSL i SD - ugrupowania programowo współdziałające z partią przewodnią;

d) PZPR jako partię ogólnonarodową vs. ZSL i SD jako partie środowiskowe ${ }^{17}$.

Analizując powyższe determinanty działalności SD w tzw. systemie trójpartyjnym $^{18}$, należy zwrócić uwagę na oczywisty fakt istnienia innej niżby chciała ówczesna propaganda odmiany totalitarnej monopartyjności, gdzie legalne organizacje rożne od partii komunistycznej działały na zasadach koncesji, stanowiły „pas transmisyjny partii do mas" oraz poddane były permanentnej kontroli oraz nomenklaturze stanowisk na różnych poziomach systemu politycznego (parlament, rząd, Rada Państwa i system terenowych rad narodowych, Blok Demokratyczny, Front Narodowy, Front Jedności Narodu, PRON, koncesjonowane związki zawodowe, samorząd gospodarczy, organizacje społeczne), ale także w funkcjonowaniu wewnętrznym.

Względną, bo w rzeczywistości ograniczanąza pomocą rozwiązań nomenklaturowo-koncesyjnych (podejmowanych wedle ustalonych zasad bądź ad hoc) oraz siłowych

16 Takiego określenia wielokrotnie używał w rozmowie z autorem niniejszego szkicu w marcu $2011 \mathrm{r}$. Tadeusz Witold Młyńczak, dwukrotny przewodniczący CK SD.

17 Por. M. Sadowski, System polityczny Polski Ludowej, Warszawa 1975, s. 37, 60-61.

18 Niezwykle trafnie oddziaływanie systemu komunistycznego zarówno na SD, jak i na ZSL ujmuje J. Wrona: Tzw. trójpartyjny sojusz PZPR-ZSL-SD w momencie jego powstania w 1949 roku oznaczat brutalne wymuszenie na ruchu ludowym i demokratycznym rezygnacji z istotnych dla ich tożsamości zatożeń ideologii oraz doktryny politycznej i ekonomicznej. PZPR ingerowata we wszystkie sprawy wewnętrzne partii w oficjalnej propagandzie nazywanych sojuszniczymi. ZSL i SD zostaty postawione przed alternatywą: albo wyrażenie zgody na taki dyktat albo samounicestwienie wiążace się z masowa dyskryminacja, a w skrajnym przypadkach z fizyczna likwidacja jej cztonków... [...] Oba ugrupowania w warunkach funkcjonowania systemu partyjnego PRL nie mogty stać się i nie staty się opozycją polityczna. Po październiku 1956 r. ZSL i SD staty się dekoracja tzw. socjalistycznej demokracji. Funkcjonowanie trzech ugrupowań politycznych (PZPR, ZSL, SD) wedtug regut i zasad określonych w $1949 \mathrm{r}$. i nieznacznie modyfikowanych przez kolejne cztery dziesięciolecia trwato do $1989 \mathrm{r}$. (J. Wrona, Przejawy kontestacji i próby dziatań opozycyjnych w SD i ZSL w latach 1945-1980, [w:] Opozycja w systemach demokratycznych i niedemokratycznych, red. K. Łabędź, M. Mikołajczyk, Kraków 2001, s. 299-300). 
(działania aparatu bezpieczeństwa), miarą wpływu Stronnictwa na rzeczywistość społeczno-polityczną była zarówno jego liczebność, jak i obecność w strukturach systemu władzy.

Czas budowania tzw. demokracji ludowej, czyli w szczególności kształtowania nowego systemu politycznego, to okres największego rozkwitu liczebnego SD, którego kulminacją był rok 1948, kiedy to odnotowano blisko 142-tysięczną masę członkowską. W latach następnych liczba ta na skutek tendencji to kopiowania sowieckich wzorców monopartyjnych przez kierownictwo PPR/PZPR radykalnie spadła i wyniosła 39 tys. (1957). Po zmianach październikowych Stronnictwo powoli odzyskiwało członków, np. w 1967 liczyło 78 tys. osób, w 1974 r. - 91 tys., natomiast już nigdy w swej historii nie było tak silne liczebnie jak w pierwszych latach powojennych. Największymi grupami społeczno-zawodowymi reprezentowanymi w SD byli pracownicy umysłowi oraz tzw. środowiska drobnotowarowe, np. w 1950 r. ci pierwsi stanowili połowę członków, natomiast rzemieślnicy, kupcy i pracownicy sektora usługowego to grupa 21- procentowa (kategorii ,inni” przyporządkowano $29 \%$ ). W połowie lat 70 . sytuacja uległa odwróceniu, co było wynikiem jednoznacznej, podrzędnej pozycji SD, które zepchnięte zostało do roli ugrupowania reprezentującego interesy przede wszystkim rzemiosła ${ }^{19}$ (w 1976 r. tzw. drobnotowarowcy to połowa bazy członkowskiej; kategoria pracowników umysłowych wynosiła 37\%, reszta $-13 \%)^{20}$.

W systemie naczelnych władz państwowych SD było obecne na każdym szczeblu, choć w żadnej sferze nie odgrywało kluczowej roli. Oficjalne dane z 1976 r. mówiły, iż reprezentacja poselska liczyła ok. $8 \%^{21}$, z udziałem w Prezydium Sejmu, Konwencie Seniorów i komisjach; przedstawiciel ugrupowania pełnił także funkcję wicemarszałka izby. Stronnictwo posiadało dwuosobową reprezentację w Radzie Państwa, łącznie ze stanowiskiem jej wiceprzewodniczącego, dzierżyło od jednej do trzech tek ministerialnych ${ }^{22}$, obsadzało stanowiska wiceministrów, szefów komitetów przy radzie ministrów (np. Komitet Drobnej Wytwórczości), stanowisko wiceprezesa NIK oraz szereg miejsc we wspomnianych już strukturach, takich jak FJN, samorząd rzemieślniczy, organizacje społeczne ${ }^{23}$ i zawodowe oraz towarzystwa regionalne.

19 Dominacja sfer rzemieślniczych w SD, obok systemowej koncesji przyznanej przez PZPR, wynikała m.in. z prób poddawania przez władze Stronnictwa interesów zmarginalizowanego rzemiosła pod uwagę czynników decyzyjnych (np. inicjatywy ustawodawcze podejmowane od początku dekady Gierka czy organizacja i kierowanie Komitetem Drobnej Wytwórczości) oraz z większej, jeśli chodzi o potencjalną pozycję społeczną i osobiste profity, atrakcyjności członkostwa w PZPR dla reprezentantów inteligencji.

20 Por. P. Winczorek, Miejsce i rola SD w strukturze politycznej PRL. Zagadnienia wybrane, Warszawa 1975, s. 95-114, Wydawnictwa Problemowe Ogólno-Polityczne, t. 1.

21 Organizacja polityczna spoteczeństwa..., s. 198.

22 Przedstawiciele SD kierowali i współkierowali resortami: łączności; handlu wewnętrznego i usług oraz rynku wewnętrznego.

23 SD posiadało znaczne wpływy w Towarzystwie Łączności z Wychodźstwem (z Polonią Zagraniczną) „Polonia”. Jego długoletnimi prezesami byli przewodniczący Centralnego Komitetu SD, Stanisław Kulczyński oraz Tadeusz Witold Młyńczak. 


\section{REALIZM POLITYCZNY A SD- OWSKIE BYTY ALTERNATYWNE}

Brytyjski filozof i publicysta Roger Scruton w swoim Stowniku myśli politycznej ${ }^{24}$ określa realizm w kontekście polityki jako sktonność do postrzegania rzeczy takimi, jakimi sa, a nie takimi, jakimi być powinny, oraz świadomość, że podstawowym celem dziatania wszystkich podmiotów politycznych jest wtadza i poprawa swej pozycji ${ }^{25}$. Badacz problemu realizmu politycznego, politolog Piotr Kimla, tworząc katalog determinantów pojęcia, wymienia pośród nich m.in. postawę nonkonformistyczną oraz obiektywizm. Nonkonformizm przeciwstawia się wizji „magicznej rzeczywistości”, kreacji utopii i pojmowania rzeczywistości w skrajnych, dychotomicznych kategoriach. Realizm, dążąc do komplementarnego ujęcia rzeczywistości i nie ograniczając się w związku z tym do sfery doktrynalno-dogmatycznej, poszukuje obiektywizmu w zastanej rzeczywistości, wobec której jest nader krytyczny.

Powyższe poglądy są tylko pozornie rozbieżne. Zarówno bowiem Scruton, jak i Kimla za podstawę swoich ujęć zdają się przyjmować ontologiczne twierdzenie, iż rzeczywistość jest uporządkowana i tworzy, jak stwierdza ten drugi, obiektywny ład oparty na prawach drzemiących w ludzkiej naturze ${ }^{26}$. Stąd realizm polityczny w obronie tego, „co jest”, rzuca rękawicę wszelakim nazbyt optymistycznym poglądom dotyczącym natury ludzkiej. W efekcie takiego ujęcia najważniejsza sfera ludzkiej aktywności, czyli polityka, nie może wpływać na tworzenie wizji „,nowego człowieka”, a jedynie odczytywać i regulować - obiektywizować rzeczywistość ${ }^{27}$.

Czy tak pojęty realizm polityczny był obecny i towarzyszył aktywności SD w okresie PRL-u, pozostaje kwestią dyskusyjną. Wydaje się jednak, że w łonie Stronnictwa dochodziło we wspomnianym okresie do mitycznej walki "dobra ze złem” - innymi słowy: do starcia dążenia oparcia polityki na realnych, obiektywnych podstawach z dogmatyczną, materialistyczną i pseudoobiektywną wizją rzeczywistości, która podpierała się propagandą wieszczącą li tylko pozornie uprawianie polityki zgodnej z prawdziwą naturą i potrzebami człowieka oraz społeczeństwa.

$\mathrm{Na}$ fali odwilży październikowej roku 1956 w „Tygodniku Demokratycznym”, organie prasowym SD, ukazał się tekst jednego z liderów środowiska dziennikarskiego Stronnictwa, w którym expressis verbis podniesiono postulat uprawiania polityki w kategoriach realizmu. Henryk Tycner przedstawił realizm jako matematykę życia politycznego i gospodarczego, określająca możliwości i drogi realizacji celów ${ }^{28}$. Dalej sformułował niemal definicję działania w oparciu o przyjętą wykładnię, którą warto przytoczyć w całości: Teraz [po VIII Plenum KC - przyp. A. T.] gdy przed narodem na-

24 R. Scruton, Stownik myśli politycznej, przeł. T. Bieroń, Poznań 2002.

25 Tamże, s. 324.

26 P. Kimla, Historycy-politycy jako źródto realizmu politycznego. Tukidydes, Polibiusz, Machiavelli, Kraków 2009, s. 152.

27 Tamże, s. 150.

28 H. Tycner, Realizm polityczny przede wszystkim, „Tygodnik Demokratyczny” 1956, nr 46, s. 1. 
szym pojawita się perspektywa bezpośredniego, samodzielnego dziatania konieczne jest dalsze wyksztatcenie w masach realizmu politycznego, jako podstawowego elementu przy wspótrządzeniu, jako jednego z niezbędnych czynników przy podejmowaniu odpowiedzialności za losy catego kraju. Obowiazkiem każdego aktywisty i dziatacza politycznego, a więc także cztonków naszego Stronnictwa jest uświadomienie masom odpowiedzialności za losy kraju i poprzez analityczne dyskutowanie wszystkich problemów uczenie realizmu politycznego 29 .

Z powyższego wynika, iż Stronnictwo Demokratyczne, wykorzystując ferment wywołany zarówno pewnym przesunięciem akcentów w polityce Związku Sowieckiego na skutek efektów XX Zjazdu KPZR, jak i wypadkami czerwcowymi w Poznaniu i ich wpływem na wymianę komunistycznego kierownictwa w Polsce, dostrzegło szansę prowadzenia samodzielnej, zgodnej z obiektywnymi wyznacznikami rzeczywistości polityki. Nic bardziej mylnego. Widoczne odcięcie się od czasów stalinowskich nie przekreśliło aksjomatu pozostawania w trójpartyjnym „sojuszu”, zwanym rytualnie „współrządzeniem”. W tym szczególnym kontekście postulaty wykształcania postawy społecznie aktywnej, odpowiedzialnej oznaczały nic innego jak zrozumienie koniecznego, czyli trwanie w utopijnej zarówno społecznie, jak i gospodarczo ${ }^{30}$ konwencji dążenia do pełni socjalizmu pod przewodem instytucjonalnej awangardy postępu: PZPR. W związku z powyższym oraz z faktem zaakceptowania pozycji „trzeciego w szeregu” i konsekwencji tego stanu (pozorna samodzielność, instrument oddziaływania na społeczeństwo), Stronnictwo jako całość nie było w stanie stworzyć realnej alternatywy dla PZPR. Koniec końców ugrupowanie, pomimo kolejnych zjazdów partyjnych - tutaj na niejakie wyróżnienie zasługuje XII Kongres z marca 1981 r., gdzie sformułowano postulaty zmian ustrojowych, takie jak zwiększenie kompetencji NSA, powołanie Trybunału Konstytucyjnego, Trybunału Stanu czy utworzenie urzędu Prezydenta Państwa - a także mimo dyskusji, sporów wewnątrzpartyjnych i walk frakcyjnych (np. starcie stalinowskich notabli z postpaździernikowym rozdaniem, walka pokoleniowa) - wspierało istniejący porządek, wpisując się w determinanty polityki partii komunistycznej. Analiza oficjalnego stanowiska SD, np. w czasie konfliktu o Millenium, wydarzeń roku 1968, grudnia roku 1970, zmian konstytucyjnych roku 1976 czy wprowadzenia stanu wojennego, nie pozostawia tutaj istotnych wątpliwości ${ }^{31}$. Warunki realizmu politycznego aż do utworzenia rządu koalicyjnego Tadeusza Mazowieckiego („Solidarność”, ZSL, SD, przedstawiciele PZPR) pozostawały więc poza zasięgiem działania Stronnictwa jako elementu sceny partyjnej i systemu politycznego.

29 Tamże.

30 Doktryna i praktyka systemu tzw. realnego socjalizmu została znakomicie zanalizowana w fundamentalnej pracy Macieja Bałtowskiego pt. Gospodarka socjalistyczna w Polsce. Geneza, rozwój, upadek, Warszawa 2009.

31 Szerzej zob.: prace Waldemara Żebrowskiego i wymieniona w niniejszym szkicu monografia Antoniego Czubińskiego, a także bardzo ciekawe studia przypadków autorstwa: Janusza Wrony pt. Zależni czy suwerenni. Stronnictwo Demokratyczne w województwie lubelskim 1944-1975, Lublin 1998 oraz Adama Drążka pt. Przy czy obok wtadzy? Stronnictwo Demokratyczne w województwie biatostockim w latach 1945-1989. Organizacja i dziatalność, Białystok 2005. 
Niemniej jednak SD stawało się niejednokrotnie forum, gdzie można było dostrzec próby aktywności w duchu realizmu politycznego - chodzi o działania sformalizowane oraz te podjęte w duchu nieformalnej opozycji wobec głównej linii politycznej ugrupowania. Tym samym mieliśmy do czynienia ze swoistą schizofrenią - organizacja mieszcząca się w centrum systemu politycznego PRL stawała się inkubatorem dla działaczy i grup kontestujących realny socjalizm.

Jednym z najbardziej charakterystycznych instytucjonalnych przykładów była animacja przy boku Stronnictwa późną jesienią 1956 r. Związku Młodych Demokratów (ZMD), z Karolem Głogowskim, Adamem Pleśniarem i Przemysławem Górnym na czele. Organizacja, nawiązując do meritum demokratycznej tradycji przedwojennego Związku Polskiej Młodzieży DemokratycznejorazZwiązku Młodzieży Demokratycznej istniejącego w latach 1945-1948, jednoznacznie opowiedziała się za wprowadzaniem zasad pluralizmu i rzeczywistej samodzielności politycznej. Było to niejako naturalnym następstwem nadziei rozbudzonych efektami XX Zjazdu KPZR i VIII Plenum KC PZPR oraz składu osobowego organizacji, znajdowali w niej bowiem miejsce ludzie jawnie krytykujący stalinizm i hołdujący poglądom różnych odcieni: od socjaldemokratycznych, przez chadeckie, aż do nawiązujących do głównego nurtu dziedzictwa endeckiego ${ }^{32}$.

ZMD swoje polityczne wyznanie wiary formułował na bazie krytyki totalizmu komunistycznego, którego esencję dostrzegano w stalinowskim Związku Młodzieży Polskiej. W jednym z grudniowych numerów „Tygodnika Demokratycznego” bez ogródek pisał o tym prof. Jerzy Jodłowski, kreśląc przyczyny powołania ZMD w dniu 30 listopada 1956 r. przez reprezentantów Łodzi, Szczecina, Poznania, Warszawy, Lublina i Wrocławia. Wyraziście podsumował on stosunek młodych demokratów do ZMP, jako do organizacji, która bez różnicowania ludzi wedtug ich przekonań spotecznych i politycznych, bez żadnej dyskusji, usitowata sobie podporzadkować cata mtodzieżi3.

Program pozytywny został sformułowany w tezach Deklaracji Ideowo-Programowej, uzupełnionych o poglądy studenta prawa, szefa Tymczasowego Zarządu Głównego ZMD Karola Głogowskiego, reprezentującego nadający ton młodym demokratom ośrodek łódzki. Podstawą działania Związku stało się dążenie do uwzględniania głosu wszystkich obywateli, bez względu na poglądy czy społeczne pochodzenie, a więc obranie kierunku na rzeczywiste demokratyczne formy funkcjonowania społeczeństwa w systemie politycznym. Istotnym zatem elementem, co podkreśla Andrzej Friszke, była negacja marksistowskiego założenia o naturalnym przyporządkowaniu każdej klasie społecznej odpowiedniej ideologii czy organizacji, co skutkowało pluralistyczną formułą programową ${ }^{34}$.

W Deklaracji czytamy: Zwiazek Mtodzieży Demokratycznej walczy o suwerenna i demokratyczna Polskę. Jak najczynniej budujemy polski modelsocjalizmu. W takowym dziele organizacyjnym demokratyczny dyskurs, czyli, jak to określił Głogowski na Zjeździe

32 A. Friszke, Opozycja polityczna w PRL 1945-1980, Londyn 1994, s. 92-93.

33 J. J[odłowski], Mtodym Demokratom naprzeciw..., „Tygodnik Demokratyczny” 1956, nr 49, s. 3.

34 Por. A. Friszke, Opozycja polityczna w PRL..., s. 92-93. 
organizacyjnym, „walka przeciwieństw”, odgrywać miał zasadniczą rolę, gdyż warunkował twórcze działanie. Takowe w dobrze, bo pluralistycznie, pojętym duchu wartości socjalistycznych miało doprowadzić do: likwidacji monopartyjności i faktycznego dopuszczenia do władzy wszystkich organizacji politycznych, reprezentujących cały przekrój społeczny, do istnienia równouprawnionych sektorów gospodarczych z naciskiem na uwzględnienie samorządu pracowniczego, do rezygnacji z systemu nomenklatury na rzecz doboru wedle kwalifikacji oraz do wolności badań naukowych ${ }^{35}$.

ZMD dostrzegało w Stronnictwie Demokratycznym naturalnego, politycznego sojusznika, w relacji z którym nie było według Związku zasadniczych różnic ideologicznych. Na spotkaniu Tymczasowego Zarządu ZMD z Prezydium CK SD, odbytym 6 grudnia 1956 r., młodzi demokraci zastrzegli jednak, iż działalność swą będą prowadzić na zasadach całkowitej niezależności i samodzielności ${ }^{36}$. Uwypuklenie od zarania działalności czynnika autonomii oraz poglądów sprzeciwiających się politycznemu dyktatowi ${ }^{37}$ sprawiło, iż w oczach samego Władysława Gomułki oraz jego ekipy ZMD stało się organizacją o znamionach opozycyjności. Szczególne zaniepokojenie miała budzić koncepcja budowy organizacji w oparciu o nieklasową, ogólnonarodową formułę, co wiązało się z ingerencją w zastrzeżony dla PZPR teren robotniczy. Pomimo prób obrony nowej inicjatywy młodzieżowej przez przedstawicieli władz centralnych SD - w połowie grudnia 1956 r. sprawie tej poświęcone były wspólne, czterodniowe obrady CK SD oraz BP KC PZPR - nacisk partii komunistycznej sprawił, iż Stronnictwo wycofało swoje poparcie dla ZMD, deklarując w dniu 11 styczniu 1957 r., że jedyną formułą organizacji młodzieży staną się Koła Młodych SD. Kilka dni później Tymczasowy ZG Związku rozwiązał oficjalne struktury organizacyjne. Działalność w konspiracji próbowała prowadzić jeszcze antykomunistyczna grupa Przemysława Górnego, jednakże ze względu na działania policji politycznej zakończyła swoją aktywnośćs ${ }^{38}$.

Rację należy przyznać Bogdanowi Hillebrandtowi, który, odnosząc się do losów ZMD z przełomu 1956 i 1957 r., konstatował, iż wycofanie poparcia Stronnictwa Demokratycznego dla Związku wynikało z niebezpiecznej dla komunistów ewolucji organizacji młododemokratycznej w kierunku legalnej opozycji politycznej, negującej niektóre rozwiązania społecznopolityczne podejmowane przez PZPR przy poparciu $\mathrm{SD}^{39}$. Tym samym proponowaną przez ZMD w duchu niezależności, odzyskiwania znamion suwerenności i racjonalności politycznej zmianę inicjowaną zastopowało dogmatyczne, a więc wrogie realizmowi politycznemu, marksistowskie stanowisko przedstawicieli ówczesnych władz. Klęska nie była zupełna, ponieważ efekty zainicjowanego dyskursu w kategoriach realizmu zrodziły zarówno wewnętrzny ferment w szeregach

35 „Tygodnik Demokratyczny” 1956, nr 49, s. 3; nr 50, s. 3.

36 „Tygodnik Demokratyczny” 1956, nr 50, s. 3.

37 Głogowski w artykule programowym bez ogródek artykułował niezgodę na jakąkolwiek zależność: Cztowiek winien mieć możność swobodnego wyboru drogi do socjalizmu. Na tej drodze nie musi się nikomu podporzadkowywać, nikomu ulegać. Nikt nie ma prawa, aby jego wzór inni uznawali za cośśsiętego wtedy, kiedy uważaja go za niestuszny... („Tygodnik Demokratyczny” 1956, nr 50, s. 3).

38 J. Wrona, Przejawy kontestacji..., s. 304-305.

39 B. Hillebrandt, Ruch mtodzieżowy w Polsce. Zarys historii postępowego nurtu, Warszawa 1982, s. 302. 
SD (np. proreformatorska dyskusja na forum Kół Młodych na przełomie lat 50. i 60., integracja wewnętrznej opozycji w ramach tzw. Ruchu Odnowy Moralnej czy inicjatywa krakowskich działaczy tworzących tzw. Komitet Naprawy Rzeczpospolitej, którego nazwą sygnowany był wielostronicowy, antysystemowy dokument pod znamiennym tytułem De Republica Emendanda), ale również jednoznaczne zaangażowanie opozycyjne. O takowym świadczą losy przywódców ZMD, takich jak Głogowski, Pleśniar czy Andrzej Ostoja-Owsiany, którzy poddani represjom organów bezpieczeństwa (inwigilacja, osadzenie w więzieniu, procesy) współtworzyli środowiska ROPCiO, Ruchu Wolnych Demokratów i KPN ${ }^{40}$.

Myślenie w kategoriach realizmu politycznego obecne było także pośród działaczy Stronnictwa, którzy niezależnie od układów frakcyjnych czy grupowych wyrażali swoje poglądy, wykorzystując jak najbardziej legalne i legitymizowane przez władze fora przekazu. Do takowych zaliczyć można zorganizowany w połowie lat 60. Ośrodek Szkolenia Aktywu SD w Wólce Leszewskiej pod Łodzią, na terenie którego odbywały się kursy szkoleniowe przeznaczone dla pracowników aparatu politycznego SD. W ich trakcie ze strony uczestników niejednokrotnie dochodziło do ostrych polemik z prelegentami - przedstawicielami władz centralnych SD, oraz do wyrażania odmiennego niż oficjalne, zazwyczaj krytycznego stanowiska. Charakterystyczne są tutaj relacje konfidencjonalne, dzięki którym można zorientować się o faktycznych nastrojach pośród członków SD. I tak jeden z uczestników kursu odbywającego się w styczniu 1966 r., Maciej Bubełła z Gdańska, wywodzacy się z kót mtodych, sugerował, aby w sprawach dotyczących stosunków państwo-Kościól, polityki zagranicznej, stosunków z ZSRR, relacji PZPR-SD czy kwestiach dotyczących przyszłości Polski prezentować własne zdanie. Co więcej, agitował, aby wypowiedzi wykładowców kursu nie traktować dosłownie ${ }^{41}$.

Podobnie rzecz się miała miesiąc później, z tym że wypowiedzi były zdecydowanie ostrzejsze, dotykające meritum podejmowanych kwestii. Z najbardziej charakterystycznych - Leonard Wytykowski, komornik Sądu Powiatowego w Gostyniu, tymi słowy miał ocenić rzeczywistą, terenową współpracę międzypartyjną: Przykre to ale prawdziwe, ten tak zwany sojusz to wielka lipa, PZPR w ogóle się z nami nie liczy, na przyktad I sekretarz PZPR w Gostyniu powiedziat, że SD może w ogóle nie istnieć, bo ta organizacja nic nie daje dla terenu $i$ to jest zawracanie gtowy. Inny uczestnik kursu z lutego 1966 r., Franciszek Tomczyk, nauczyciel z Ostrowa Wielkopolskiego, podniósł kwestię pozornego wpływu działań politycznych SD w kontekście lokalnym i systemowym: $W$ ogóle traktuje się SD jak zto konieczne i gadanie w Ośrodku o wspótrządzeniu i wspótodpowiedzialności SD jest czcza gadanina i demagogia ${ }^{42}$.

40 Szerzej zob. np.: Opozycja w PRL. Stownik biograficzny 1956-1989, red. nacz. J. Skórzyński, t. 1, Warszawa 2000; t. 3, Warszawa 2006 - biogramy: K. Głogowskiego i A. Pleśniara; także: G. Waligóra, Ruch Obrony Praw Cztowieka i Obywatela 1977-1981, Warszawa 2006, Monografie / Instytut Pamięci Narodowej. Komisja Ścigania Zbrodni przeciwko Narodowi Polskiemu, t. 29.

41 Archiwum Instytutu Pamięci Narodowej w Warszawie (dalej: AIPN BU), sygn. 0236/34/2, Meldunek nr 94/66 z dnia 24 lutego 1966 r. - źródło „Waldemar”, k. 12-13.

42 Tamże, k. 13-14. Przytoczona opinia w sposób jaskrawy i bezlitosny weryfikuje oficjalne stanowisko PZPR odnośnie do tzw. współrządzenia, wyrażone przez W. Gomułkę w dniu 15 stycznia 1958 r. na 
Kwintesencją podobnych nastrojów, ale i podsumowaniem rozważań rozstrzygających w pewnej mierze o obecności realizmu politycznego w działaniach Stronnictwa Demokratycznego w okresie PRL niech będą słowa cytowanego uprzednio Macieja Bubełły, który w węższym gronie jednoznacznie stwierdził, iż nie wolno nigdy zapominać, $\dot{z}$ e mimo pozorów stwarzanych przez PZPR Polską rządzi sięnadal z Moskwy ${ }^{43}$. Faktyczny udział w niesuwerennej władzy, która opierała się na antyobiektywnych, dogmatycznych przesłankach, wyklucza więc SD z grona bytów hołdujących realizmowi politycznemu. Nie przekreśla to jednak faktu, iż niektórzy członkowie czy grupy wewnątrz Stronnictwa dążyły do zmiany takiego stanu rzeczy. Jeśli działo się to ze szlachetnych i szczerych pobudek - jak u Głogowskiego czy Górnego - realizm w polityce był ich udziałem. Jeżeli zaś były to działania pozorowane i służyły li tylko umocnieniu własnej pozycji czy realizacji obcych interesów, mieliśmy do czynienia z cynicznym oportunizmem.

\section{BIBLIOGRAFIA}

Archiwum Instytutu Pamięci Narodowej w Warszawie, sygn. 0236/34/2.

Bałtowski M., Gospodarka socjalistyczna w Polsce. Geneza, rozwój, upadek, Warszawa 2009.

Czubiński A., Stronnictwo Demokratyczne (1937-1989). Zarys dziejów, Poznań 1998, Publikacje Instytutu Historii UAM, 24.

Deklaracja Ideowa podziemnego Stronnictwa Demokratycznego z września 1940 r., „Zeszyty Historyczno-Polityczne Stronnictwa Demokratycznego" 1988, nr 1.

Drążek A., Przy czy obok wtadzy? Stronnictwo Demokratyczne w województwie biatostockim w latach 1945-1989. Organizacja i dziatalność, Białystok 2005.

Friszke A., Opozycja polityczna w PRL 1945-1980, Londyn 1994.

Gomułka W., O naszejpartii, Warszawa 1969.

Hillebrandt B., Ruch mtodzieżowy w Polsce. Zarys historii postępowego nurtu, Warszawa 1982.

J[odłowski] J., Mtodym Demokratom naprzeciw..., „Tygodnik Demokratyczny” 1956, nr 49.

Kimla P., Historycy-politycy jako źródto realizmu politycznego. Tukidydes, Polibiusz, Machiavelli, Kraków 2009.

Materiaty do historii Klubów Demokratycznych i Stronnictwa Demokratycznego w latach 1937-1939, cz.1, wstęp i oprac. L. Chajn, Warszawa 1964.

Opozycja w PRL. Stownik biograficzny 1956-1989, red. nacz. J. Skórzyński, t. 1, Warszawa 2000; t. 3, Warszawa 2006.

Organizacja polityczna spoteczeństwa socjalistycznego w Polsce, red. A. Dobieszewski, Warszawa 1977.

Projekt „Deklaracji Ideowej” opracowany w krakowskim ośrodku podziemnego SD (fragment), „Zeszyty Historyczno-Polityczne Stronnictwa Demokratycznego” 1990, z. 4.

kolejnym Kongresie SD: My i wy - PZPR i SD - wspótpracujemy blisko i codziennie [...]. W przekonaniu naszej partii jest to wspótpraca ptodna, pożyteczna dla Polski, dla ludzi pracy, dla rozwoju budownictwa socjalistycznego w naszym kraju (W. Gomułka, O naszej partii, Warszawa 1969, s. 382).

43 AIPN BU, sygn. 0236/34/2, k. 14 . 
Sadowski M., System polityczny Polski Ludowej, Warszawa 1975.

Scruton R., Stownik myśli politycznej, przeł. T. Bieroń, Poznań 2002.

Stronnictwo Demokratyczne w Polsce Ludowej, cz. 1: Wybór dokumentów z lat 1944-1949, Warszawa 1968.

Tycner H., Realizm polityczny przede wszystkim, „Tygodnik Demokratyczny” 1956, nr 46.

Tyszka K., Nacjonalizm w komunizmie. Ideologia narodowa w Związu Radzieckim i Polsce Ludowej, Warszawa 2004.

Uchwata Zjednoczenia Demokratycznego [1945], „Zeszyty Historyczno-Polityczne Stronnictwa Demokratycznego" 1990, nr 3.

Waligóra G., Ruch Obrony Praw Cztowieka i Obywatela 1977-1981, Warszawa 2006, Monografie I Instytut Pamięci Narodowej. Komisja Ścigania Zbrodni przeciwko Narodowi Polskiemu, t. 29.

Winczorek P., Miejsce i rola SD w strukturze politycznej PRL. Zagadnienia wybrane, Warszawa 1975, Wydawnictwa Problemowe Ogólno-Polityczne, t. 1.

Wrona J., Przejawy kontestacji i próby dziatań opozycyjnych w SD i ZSL w latach 1945-1980, [w:] Opozycja w systemach demokratycznych i niedemokratycznych, red. K. Łabędź, M. Mikołajczyk, Kraków 2001.

Wrona J., SD w systemie politycznym PRL 1944-1965. Studium krytyczne, „Zeszyty Historyczno-Polityczne Stronnictwa Demokratycznego" 1990, nr 3.

Wrona J., System partyjny w Polsce 1944-1950. Miejsce, funkcje, relacje partii politycznych w warunkach budowy $i$ utrwalania systemu totalitarnego, Lublin 1997.

Wrona J., Zależni czy suwerenni. Stronnictwo Demokratyczne w województwie lubelskim 1944-1975, Lublin 1998.

Żebrowski W., Stronnictwo Demokratyczne w warunkach demokratyzacji ustroju politycznego, Olsztyn 2003.

Dr Adrian TYSZKIEWICZ - adiunkt w Katedrze Historii Polski Współczesnej INPiSM UJ, stypendysta Funduszu Pomocy Niezależnej Kulturze i Nauce Polskiej oraz Fundacji na Rzecz Nauki Polskiej, autor prac dotyczących polskich ruchów politycznych w II RP i PRL (nacjonalizm, myśl państwowa, lewica piłsudczykowska i społeczna) oraz historii polskich koncepcji geopolitycznych (W. Sikorski, J. Beck), recenzent „Politei”. 